TARNOWSKIE STUDIA TEOLOGICZNE 36 (2017) NR 1, S. 21-36

http://dx.doi.org/10.15633/tst.2322

ks. Jacek Siewiora ${ }^{1}$

MAŁOPOLSKA WYŻSZA SZKOŁA EKONOMICZNA W TARNOWIE

\title{
Miłosierdzie jako kategoria życia społecznego
}

Na przestrzeni ostatnich kilku dekad możemy zaobserwować zwiększone zainteresowanie miłosierdziem, co zrodziło konieczność uporządkowania poglądów na jego temat. Stało się ono zatem przedmiotem refleksji teologicznej, włącznie z kluczową encykliką Dives in misericordia Jana Pawła II, w której przypominał on, że im bardziej posłannictwo - także w wymiarze miłosierdzia, jakie spełnia Kościół - jest skoncentrowane na człowieku, im bardziej jest, rzec można, „antropocentryczne”, tym bardziej musi potwierdzać się i urzeczywistniać teocentrycznie ${ }^{2}$. Wzmocnienie instytucjonalnego i duszpasterskiego zaangażowania Kościoła w dzieła miłosierdzia znalazło między innymi wsparcie i podbudowę w fakcie ogłoszenia przez Ojca św. Franciszka Roku Miłosierdzia. Podejmując refleksję nad rzeczywistością miłosierdzia w życiu społecznym, a więc także w przestrzeni pedagogicznej, należy się zastanowić, czy miłosierdzie jest w tym kontekście oznaką słabości i rezygnacji z wymagań, czy przeciwnie - znakiem rzetelnej troski o jakość życia społecznego i rozwój młodego pokolenia, za które jako duszpasterze, katecheci, wychowawcy czy rodzice odpowiadamy.

\section{Miłosierdzie - przejaw słabości czy siły społeczeństwa}

We współczesnej socjologii rozważania nad tym, czym jest społeczeństwo, prowadzą do odchodzenia w jego definiowaniu od określania go jako zbiorowości, ku swoistemu pojmowaniu go jako rzeczywistości, która manifestuje

1 Ks. dr hab. Jacek Siewiora, profesor nadzwyczajny Małopolskiej Szkoły Ekonomicznej w Tarnowie. Autor wielu publikacji z zakresu pedagogiki i katechetyki. Obszary zainteresowań naukowych: dydaktyka katechezy, aksjologia wychowania, pedagogika społeczna, metodyka pracy pedagoga.

2 Zob. Jan Paweł II, Encyklika o Bożym Miłosierdziu Dives in misericordia, Kraków 2010, nr 1 [dalej: DM]. 
się w najrozmaitszy sposób. Tym samym jak uważa Piotr Sztompka „społeczeństwo to wszystko to, co dzieje się pomiędzy ludźmi” bądź „suma zdarzeń dziejących się w przestrzeni międzyludzkiej”3. Oczywiste jest, że poszczególne osoby, jako członkowie społeczeństwa, podejmują różnorakie formy działalności, budując te międzyludzkie zdarzenia. $Z$ racji zarysowanego tematu interesują nas jednak tylko te $\mathrm{z}$ nich, które są wynikiem świadomie podejmowanych, dynamicznych, ciągłych sekwencji nawzajem zwróconych ku sobie działań społecznych, czyli interakcje $e^{4}$. Podłożem tych interakcji są, co oczywiste, działania wychowawcze, oraz miejsce, jakie w nich zajmuje miłosierdzie, rozumiane jako kategoria, czyli cecha konstytutywna życia społecznego 5 .

Miłosierdzie z perspektywy teologicznej definiowane jest jako „pełna miłości troskliwość Boga o wszystkie stworzenia, a zwłaszcza o ludzi, która nas zachęca do okazywania współczucia innym i do niesienia im ulgi"6. Wskazuje się przy tym, że mówiąc o miłosierdziu, Stary Testament wykorzystuje aż trzy wyrażenia:

- hesed - „dobrotliwość”, czyli wierna życzliwość, która się opiera albo na umowie podobnej do umowy małżeńskiej ( $\mathrm{Rdz} 20,13$ ), albo na ścisłej przyjaźni (1 Sm 20, 8, 14-15). Słowo to stosowane jest zatem tylko w przypad$\mathrm{ku}$, gdy istnieje jakaś więź pomiędzy zainteresowanymi stronami, a w szerszym znaczeniu używane jest jako słowo przymierza, zwłaszcza między Bogiem a Izraelem, jest owocem historii relacji Boga z Jego przymierza ludzi ${ }^{7}$.

- rahamín - „łono” - jest to pewna sympatia albo współczucie podobne do tego, jakie odczuwa matka do swego dziecka (Iz 49, 15);

- hen - „łaska”, oznacza, że umiłowanie Boże zostało dane darmo i niezależnie od zasług przyjmującego $(\mathrm{Wj} 33,12-17)^{8}$.

Miłosierdzie jest więc gotowością przyjścia z pomocą temu, kto znajduje się w jakiekolwiek potrzebie. Dla teologii chrześcijańskiej miłosierdzie Boga wynika już z faktu, że jest On nieskończony w każdej swej doskonałości,

3 P. Sztompka, Socjologia. Analiza społeczeństwa, Kraków 2012, s. 36-37.

4 Zob. P. Sztompka, Socjologia. Analiza społeczeństwa, s. 81.

5 Zob. http://sjp.pwn.pl/sjp/kategoria;2563203.html (5.07.2016).

6 G. O’Collins, E. G. Farrugia, Leksykon pojęć teologicznych i kościelnych, Kraków 2002, s. 18 o.

7 Zob. http://www.bible-researcher.com/chesed.html (5.07.2016).

8 Zob. G. O’Collins, E. G. Farrugia, Leksykon pojęć teologicznych i kościelnych, s. 180-181. 
jednakże szczególnie podkreślana jest wolność Boga w udzielaniu miłosierdzia. Tym samym człowiek, który rzeczywiście zasłużył na sąd, nie może na nie liczyć, lecz może je tylko z wdzięcznością przyjąć jako doświadczenie historiozbawcze ${ }^{9}$. Istotne jest, $\mathrm{z}$ naszego punktu widzenia, że Biblia wskazuje, iż miarą miłosierdzia ludzkiego nie są uczucia, lecz konkretne jego dowody. Gotowość do podejmowania w codziennym życiu obowiązku bycia miłosiernym wynika w takim razie z odkrycia prawdy, że sami dostąpiliśmy miłosierdzia ${ }^{10}$.

Tradycyjna etyka katolicka zalicza miłosierdzie do cnót społecznych, wskazując, że działanie tej cnoty łączy się ściśle z czynną miłością bliźniego, niemniej jednak nie utożsamia się z nią. Według Jacka Woronieckiego, który buduje swoją intuicję w oparciu o myśl św. Tomasza, miłosierdzie od miłości bliźniego różni się celem. Miłość dąży do tego, aby przyczynić się do dobra bliźniego, a celem miłosierdzia jest usunięcie zła, które mu dolega ${ }^{11}$. Niezwykły wkład w rozumienie koncepcji miłości miłosiernej wniósł Jan Paweł II. W encyklice Dives in misericordia miłosierdzie ukazane zostało jako uzewnętrznienie się miłości względem człowieka znajdującego się w drodze, obarczonego ciężarem swoich słabości. W swym „eschatologicznym spełnieniu, miłosierdzie objawi się jako miłość, podczas gdy w doczesności, w dziejach człowieka, które są zarazem dziejami grzechu i śmierci, miłość musi objawiać się nade wszystko jako miłosierdzie i wypełniać się również jako miłosierdzie" ${ }^{\prime 2}$. W takim ujęciu miłosierdzie jest nie już tylko cnotą, ale przede wszystkim postawą, która suponuje istnienie całego zespołu sprawności moralnych. Wśród nich na pierwszy plan wysuwa się owa twórcza miłość, która nie daje się zwyciężyć złu, ale zło dobrem zwycięża. Właściwa chrześcijaninowi, jako ideał, postawa miłosierdzia wyraża się w różnych aktach zarówno wewnętrznych, jak i zewnętrznych. Przede wszystkim jednak w miłosierdzie trzeba uwierzyć, potem je głosić, następnie wprowadzać w czyn, trzeba doświadczać miłosierdzia i błagać o miłosierdzie $^{13}$. Płynie z tego wniosek, że jakość życia społecznego może wydatnie

9 Zob. K. Rahner, H. Vorgrimler, Mały słownik teologiczny, Warszawa 1987, k. 233-234.

${ }^{10}$ K. Rahner, H. Vorgrimler, Mały słownik teologiczny, k. 233-234.

${ }^{11}$ Zob. J. Woroniecki, Katolicka etyka wychowawcza, t. 3, Lublin 2013, s. 28.

12 DM, nr 8.

${ }^{13}$ Zob. K. M. Kasperkiewicz, Pojęcie miłosierdzia $w$ encyklice „Dives in misericoridia”, w: Encyklika Ojca Świętego Jana Pawła II o Bożym miłosierdziu „Dives in misericordia”. Tekst i komentarz, red. S. Grzybek, M. Jaworski, Kraków 1981, s. 67. 
się poprawić, jeżeli chrześcijanie zechcą być konsekwentni w wprowadzaniu w czyn aktów miłości miłosiernej. Warto w tym miejscu wskazać, odwołując się do nauczania Jana Pawła II, cechy konstytutywne miłości miłosiernej. Graficznie zostały przedstawione poniżej.

Rys. Cechy konstytutywne miłości miłosiernej

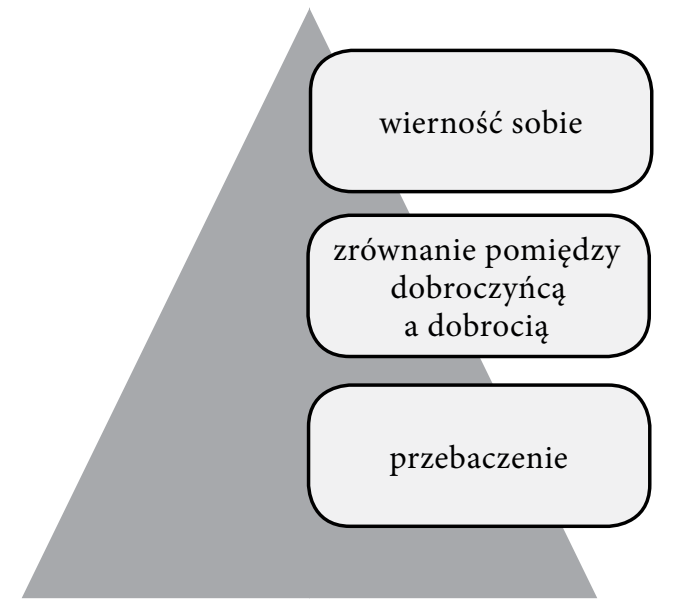

Źródło: opracowanie własne.

- Istotnym elementem budującym postawę „miłości miłosiernej” jest wierność sobie. Ta właśnie wierność znajduje się u podstaw miłosierdzia i je warunkuje. Bóg jest miłosierny, ponieważ jest wierny swej odwiecznej miłości względem człowieka, natomiast człowiek jest miłosierny, o ile pozostaje wierny tej miłości, jaką powinien darzyć drugiego człowieka. Do natury zaś miłości należy to „że nie może ona nienawidzić i pragnąć zła tego, kogo raz sobą obdarzyła"14. W tym znaczeniu wiernym sobie jest Bóg jako Stwórca, który związał się szczególną miłością ze swoim stworzeniem. Najbardziej wymownym świadectwem Boga bezwzględnie wiernego swojej odwiecznej miłości do człowieka jest krzyż, na którym Jego jednorodzony Syn poniósł śmierć ${ }^{15}$.

\footnotetext{
$14 \mathrm{DM}, \mathrm{nr} 4$.

15 Zob. DM, nr 7.
} 
- Drugim istotnym elementem postawy miłosierdzia, który nadaje miłosierdziu właściwą postać i decyduje o jego autentyczności, jest zrównanie pomiędzy czyniącym miłosierdzie a doznającym go, „pomiędzy dobroczyńcą a dobrobiorcą" ${ }^{\text {"16 }}$. Według Jana Pawła II, w każdym wypadku uaktywniania się miłosiernej miłości dokonuje się niezwykła wymiana i każdorazowo dobroczyńca jest równocześnie odbiorcą dobra. „Nawet w wypadkach, w których wszystko zdawałoby się wskazywać na to, że jedna strona tylko obdarowuje, daje - a druga tylko otrzymuje, bierze - (jak np. w wypadku lekarza, który leczy, nauczyciela, który uczy, rodziców, którzy utrzymują i wychowują swoje dzieci, ofiarodawcy, który świadczy potrzebującym), w istocie rzeczy zawsze również i tu pierwsza strona jest obdarowywana" ${ }^{\text {"17 }}$. Wymiana darów pomiędzy dobroczyńcą a odbiorcą dobra jest wieloaspektowa. Wydaje się także oczywiste i łatwe do wyjaśnienia, na czym polega kierunek wymiany dóbr płynących od darczyńcy ku obdarowanemu. Odwrotny kierunek może nastręczać pewne trudności w zrozumieniu istoty tej wymiany. Jednak intuicja Jana Pawła II każe nam dostrzegać, iż stanięcie wobec ludzkiej potrzeby daje okazję darującemu do przeżycia aktu miłosiernej miłości niezależnie od tego, jak ten dar zostanie przyjęty. Jeżeli ten akt spotyka się z wdzięcznością odbiorcy dobra, wówczas w dającym wyzwala radość, być może nawet większą od radości obdarowanego. Radość ta ma moc twórczą, ponieważ staje się bodźcem do nowych aktów miłosiernej miłości, tym samym przyczyniając się rozwoju darczyńcy jako osoby. Tym samym ten, kto przyjmuje dar z wdzięcznością, wyświadcza dobro darującemu, daje mu bowiem okazję do rozwoju moralnego, do postępu w cnocie i do zasługi ${ }^{18}$.

- Trzecią cechą, być może najważniejszą z tych budujących miłość miłosierną, jest przebaczenie. Pod tym względem, według Jana Pawła II, również konieczne jest swoiste zrównanie. Ten, kto przebacza, jak i ten, który potrzebuje przebaczenia, powinni uświadomić sobie fakt, że zazwyczaj są wobec siebie dłużnikami. Wtedy „ten, kto przebacza i ten, który dostępuje przebaczenia spotykają się z sobą. W jednym zasadniczym punkcie: tym punktem jest godność, czyli istotna wartość człowieka, która nie może

$16 \mathrm{DM}, \mathrm{nr} 14$.

${ }^{17} \mathrm{DM}, \mathrm{nr} 14$.

${ }_{18}$ Zob. K. M. Kasperkiewicz, Pojęcie miłosierdzia..., s. 70. 
być zagubiona, której potwierdzenie czy odnalezienie stanowi też źródło największej radości”'19.

\section{Miłosierdzie w przestrzeni pedagogicznej}

Zasadnicze pytanie, jakie należy w tym miejscu postawić, dotyczy wątpliwości, czy w przestrzeni pedagogicznej jest miejsce na miłosierdzie. Jeżeli opiszemy ową przestrzeń pedagogiczną jako tę, która obejmuje działania systemowe i pozasystemowe, oficjalne i nieoficjalne, dokonujące się na gruncie rodziny, w szkole i placówkach oświatowych, to trudność w udzieleniu jednoznacznej odpowiedzi na kluczowe pytanie zostanie wzmocniona. Nie ułatwia jednoznacznego rozstrzygnięcia tej kwestii potoczne postrzeganie miłosierdzia jako dobroci, dobroduszności, dobrotliwości, wspaniałomyślności, pobłażliwości czy wyrozumiałości. Wydaje się, że w codziennej praktyce miłosierdzie jest postawą, jakiej oczekują podmioty zależne od tych, które w danym układzie międzyludzkim stoją wyżej. Zatem miłosierdzia w praktyce pedagogicznej od nauczyciela oczekują uczniowie, ci natomiast oczekują go od przełożonych. Należy skonstatować, że jest ono płaszczyzną uznawania wyższości jakichś osób w celu pozyskania od nich życzliwości, do której tak naprawdę nie ma się prawa. Tkwi tu zatem fundamentalne przeświadczenie o przeciwstawności dwóch postaw: miłosierdzia i sprawiedliwości. Tymczasem miłosierdzie w Piśmie Świętym jest kluczowym słowem na określenie postępowania Boga w stosunku do nas. On nie ogranicza się do deklarowania swojej miłości, ale wyraża ją w sposób widoczny i namacalny. Miłość zresztą nie może być nigdy abstrakcyjnym słowem. Z samej swej natury jest konkretnym życiem: intencjami, zachowaniami i postawami wyrażanymi w codzienności. Miłosierdzie Boga jest Jego odpowiedzialnością za nas. On czuje się odpowiedzialny, czyli pragnie naszego dobra i chce, byśmy byli szczęśliwi, napełnieni radością i pokojem. W tym samym kierunku powinna zmierzać miłość miłosierna chrześcijan. Tak jak kocha Ojciec, tak też powinny kochać dzieci. Jak On jest miłosierny, tak też i my jesteśmy wezwani, by być miłosierni - jedni wobec drugich ${ }^{20}$.

19 Zob. DM, nr 14, także K. M. Kasperkiewicz, Pojęcie miłosierdzia..., s. 68-7o.

${ }^{20}$ Zob. Franciszek, Bulla ustanawiająca nadzwyczajny Jubileusz Miłosierdzia Misericordiae Vultus, Wrocław 2015, nr 9 [dalej: Mv]. 
Antropologia, jaką współcześnie się promuje, spycha jednak ideę miłosierdzia na margines życia społecznego. Akcentowanie ludzkiej godności, afirmacja postępu, wysuwanie na pierwszy plan wolności służy niestety zaprzeczaniu rzeczywistości grzechu, a więc w dalszej kolejności potrzebie odkupienia i przebaczenia. Już Jan Paweł II wskazywał, że samo słowo i pojęcie „miłosierdzie” jakby przeszkadza współczesnemu człowiekowi, który poprzez nieznany przedtem rozwój nauki i techniki bardziej niż kiedykolwiek w dziejach stał się panem i uczynił sobie ziemię poddaną (por. $\mathrm{Rdz} 1,28)$. Owo „panowanie nad ziemią”, rozumiane nieraz jednostronnie i powierzchownie, jakby nie pozostawia miejsca dla miłosierdzia ${ }^{21}$. Podobny problem w organizacji życia społecznego, który ma także swoje pedagogiczne konsekwencje, można obserwować w rozumieniu miłości, miłosierdzia, sprawiedliwości i ich wzajemnych oddziaływań.

Priorytet miłości wydaje się czymś oczywistym, jednak jej przejawy w działaniu człowieka już nie są tak czytelne. Miłość bowiem nie jest i nie musi być zawsze fascynacją dobrem i pięknem, jakie odnajdujemy w drugim człowieku, niekiedy musi się przejawiać jako sprzeciw wobec zła dostrzeganego w zachowaniu bliźniego ${ }^{22}$. Istotny jest jednak fakt, że relacja miłosierdzia opiera się na wspólnym przeżywaniu tego dobra, jakim jest człowiek, na wspólnym doświadczeniu tej godności, jaka jest mu właściwa, co jest możliwe także wtedy, kiedy godność ta jest przyćmiona, bo „w swoim właściwym i pełnym kształcie miłosierdzie objawia się jako dowartościowanie, jako podnoszenie w górę, jako wydobywanie dobra spod wszelkich nawarstwień zła, które jest w świecie i w człowieku. Miłosierdzie jest więc tą miłością, która "nie daje się zwyciężyć złu, ale zło dobrem zwycięża» $(\mathrm{Rz} 12,21)^{\prime 23}$.

Trudne jawi się ustalenie relacji między sprawiedliwością i miłością, gdyż tradycyjnie przeciwstawiano je sobie, akcentując prymat sprawiedliwości, a dla miłości w życiu społecznym rezerwując jedynie funkcję uzupełniającą. Miłość miała się więc zaczynać tam, gdzie kończyła się sprawiedliwość.

Inny sposób ujmowania stosunku między sprawiedliwością i miłością wyznacza w życiu społecznym tym dwom zasadom i cnotom różne, ale

\footnotetext{
${ }^{21}$ Zob. DM, nr 2.

${ }^{22}$ Zob. J. Woroniecki, Katolicka etyka wychowawcza, t. 3, s. 69.

${ }^{23} \mathrm{DM}, \mathrm{nr}$ 6, zob. J. Majka, Miłosierdzie jako zasada społeczna $w$ świetle encykliki „Dives in misericordia", w: Encyklika Ojca Świętego Jana Pawła II o Bożym miłosierdziu..., s. 179.
} 
komplementarne funkcje. Sprawiedliwość jest więc rozumiana jako miara ładu społecznego, miłość natomiast jako jego motyw i spoiwo. Podstawą sprawiedliwości jest $\mathrm{w}$ tym ujęciu przede wszystkim prawo naturalne, miłość jest natomiast niezbędnym warunkiem pełnienia sprawiedliwości ${ }^{24}$. Taka jest też myśl Jana Pawła II, który upatrywał w miłości przede wszystkim siłę jednoczącą: „powołanie chrześcijańskie polega na stałym odkrywaniu oraz wytrwałym, pomimo wszystkich trudności natury psychologicznej i społecznej, urzeczywistnianiu miłości jako siły jednoczącej i dźwigającej zarazem: miłości miłosiernej, która jest ze swej istoty miłością twórczą" ${ }^{25}$. Znajdujemy tu opis zarówno samego mechanizmu owego jednoczenia przez miłość, jak i jej stosunku do sprawiedliwości. „Autentyczne miłosierdzie jest jakby głębszym źródłem sprawiedliwości” ${ }^{26}$. Sprawiedliwość jest przede wszystkim miarą równości, odwołującą się do równej godności osobowej wszystkich ludzi, a jej podstawowym wymogiem jest przywracanie tej równości, słuszności wszędzie tam, gdzie została ona naruszona. Otóż owo autentyczne przywrócenie równości może się dokonać jedynie przez miłosierną miłość, „która jest zdolna przywracać człowieka samemu człowiekowi”27.

Dla rodziców, wychowawców, katechetów i duszpasterzy płynie z tego niezwykły wniosek, oto bowiem akty miłosiernej miłości, czynią większym i tego, który daje, i tego który otrzymuje. Nie chodzi tu o zrównanie czysto zewnętrzne, nie jest to także zrównanie polegające na wyeliminowaniu wszelkich różnic, idzie o zrównanie w godności człowieczeństwa obdarzonego godnością Bożej przyjaźni ${ }^{28}$.

Należy przy tym poczynić dwa zastrzeżenia w odniesieniu do rzeczywistości pedagogicznej. Najpierw należy pamiętać, że mowa o zrównaniu osoby nauczyciela i ucznia nie jest bynajmniej wezwaniem do pomieszania ról i zatarcia różnic pomiędzy nimi, czy zatracenia szczególnej roli nauczyciela w procesie kształcenia. Idzie raczej o zrozumienie, że relacje nauczyciel, wychowawca - uczeń winny być budowane na gruncie miłości miłosiernej. W praktyce dla nauczycieli i wychowawców oznacza to konieczność zabiegania o konkretne cechy, którymi są:

\footnotetext{
${ }^{24}$ Zob. J. Majka, Miłosierdzie jako zasada społeczna..., s. 181-182.

${ }^{25} \mathrm{DM}, \mathrm{nr} 14$.

${ }^{26} \mathrm{DM}, \mathrm{nr} 14$.

${ }^{27} \mathrm{DM}, \mathrm{nr} 14$.

${ }^{28}$ Zob. J. Majka, Miłosierdzie jako zasada społeczna..., s. 181-182.
} 
- Dojrzałość ludzka, czyli zdolność do oceny swojego postępowania, także tego zawodowego, równowaga uczuciowa, jedność wewnętrzna, zdolność do relacji i dialogu, umiejętność współdziałania $\mathrm{z}$ innymi ${ }^{29}$.

- Gotowość bycia wychowawcą, czyli kimś, kto świadomie, celowo i w sposób twórczy towarzyszy tym, którzy są mu „zadani”, którzy bardziej lub mniej świadomie, w zależności od swojego potencjału i stopnia rozwoju dążą do dojrzałości i pragną samorealizacji. Wychowawcy potrzebna jest „intuicja oraz nabycie zdolności oceny, umiejętność podejmowania decyzji i dochodzenia do źródeł osobowości - życia wewnętrznego"30.

- Rozumienie, że działanie wychowawcze wobec uczniów nie może ograniczać się reagowania na kryzys i sprowadzać się do redukowania strat takiej sytuacji. Tym, co powinno być w centrum ich działania, jest wspieranie wychowanków w rozwoju i proponowanie tym samym dojrzałej sztuki życia ${ }^{31}$.

- Kierowanie się taktem, wrażliwością, zdolnością do rozumienia i akceptowania drugiego, nabycie umiejętności motywowania do pracy nad sobą nakierowanej na osiągnięcie dojrzałości ludzkiej i chrześcijańskiej³2.

- Bycie człowiekiem i nauczycielem dialogu, który jest świadom, że od jego kompetencji komunikacyjnych w pewien sposób może być zależne przyszłe życie wiary katechizowanych. Niezbędna jest do tego pasja wychowawcza, umiejętność przystosowania oraz poszanowanie wolności innych ${ }^{33}$.

- Bycie animatorem ${ }^{34}$, czyli zdolnym do nawiązywania głębokich relacji w duchu dialogu, by w ten sposób fascynować katechizowanych sprawami wiary, sprzyjać samodzielności jednostek, budzić poczucie odpowiedzialności za podejmowane decyzje, ożywiać zaangażowanie w proces nauczania - uczenia się realizowany podczas katechezy. Katecheta-animator wykorzystuje i potrafi wyzwolić u uczniów pozytywne motywacje, które staną się podstawą ich zaangażowania w proces nauczania - uczenia się ${ }^{35}$. Przydatna jest tu tzw. „mentalność zwycięzcy”, która w zachowaniu katechety przejawia się cierpliwością i pogodą ducha. Dzięki tym cechom łatwiej jest

${ }^{29}$ Zob. E. Albieri, Katecheza dzisiaj, Warszawa 2003, s. 302, także Kongregacja ds. Duchowieństwa, Dyrektorium ogólne o katechizacji, Poznań 2002, nr 239 [dalej: DoK].

${ }^{30}$ M. Nowak, Teorie i koncepcje wychowania, Warszawa 2008, s. 168.

${ }^{31}$ Zob. M. Dziewiecki, Komunikacja wychowawcza, Kraków 2005, s. 244.

${ }^{32}$ Zob. DoK, nr 244.

${ }_{33}$ Zob. R. Czekalski, Katecheza komunikacja wiary, Płock 2006, s. 329.

${ }^{34}$ Zob. E. Albieri, Katecheza dzisiaj, s. 303.

35 Zob. M. M. Fitsula, Pedahohika, Kyiv 2007, s. 144. 
zafascynować katechizowanych perspektywą życia chrześcijańskiego, czyli miłością, prawdą, wolnością i radością ${ }^{36}$.

- Bycie dobrym dydaktykiem, co znajduje swoją realizację w umiejętności właściwego planowania zajęć, precyzyjnego określania celów lekcji, rozbudzania zainteresowań uczniów i wyzwalania motywacji do nauki i pracy na katechezie, stosowania różnorodnych toków lekcyjnych, metod i środków dydaktycznych, oraz znajomość i zdolność wykorzystania cyklów, etapów uczenia się. Niezbędna jest też umiejętność obserwacji, zdolność do refleksji i wyciągania wniosków oraz umiejętność budowania uogólnien ${ }^{37}$.

- Gotowość do przyjęcia informacji, że ludzie potrafią myśleć. Takie nastawienie pozwala nauczycielowi uwierzyć w kompetencje intelektualne uczniów oraz pozostawiać im duże pole do samodzielnego myślenia i działania, a także brania odpowiedzialności za swoje zachowanie i uczenie się $3^{38}$. Kompetentny katecheta powinien więc starać się wykorzystywać wszelkie okazje do tego, aby pomóc katechizowanym zrozumieć samego siebie oraz świat, w którym żyje i przypominać, że mądry człowiek posługuje się swoją zdolnością myślenia wyłącznie w tym celu, aby szukać prawdy ${ }^{39}$.

- Gotowość do przyjęcia informacji, że ludzie mogą się zmieniać, która na gruncie kształcenia i wychowania może stać się podstawą do optymizmu pedagogicznego i zachęcać do podejmowania wysiłku pracy nad sobą i wspierania $\mathrm{w}$ formacji innych ${ }^{40}$. W praktyce proces przemiany rozumiany będzie jako szansa rozwoju, którą katecheta winien wspierać poprzez budowanie motywacji pozytywnej, czyli umiejętne wskazywanie uczniom, że praca nad sobą nie jest przykrym obowiązkiem, ale sposobem doskonalenia osobistego i zarazem źródłem satysfakcji z tym związanej. Innymi sposobami wspierania tego procesu pozytywnej zmiany są: egzekwowanie naturalnych błędów popełnianych przez danego ucznia, postrzeganie uczniów w sposób realistyczny, obejmujący wszystkie sfery ludzkiej rzeczywistości ${ }^{41}$.

${ }^{36}$ Zob. M. Dziewiecki, Komunikacja wychowawcza, s. 258.

${ }_{37}$ Zob. L. Jarząbek, Kompetencje pedagogiczno-osobowościowe katechetów w ich ocenie oraz w opinii uczniów, w: Struktury pedagogiczne w katechezie, red. M. Śnieżyński, Kraków 2001, s. 66.

${ }^{38}$ Zob. D. Pankowska, Nauczyciel w perspektywie analizy transakcyjnej, Lublin 2010, s. 128.

39 Zob. M. Dziewiecki, Komunikacja wychowawcza, s. 138.

${ }^{40}$ Zob. D. Pankowska, Nauczyciel w perspektywie analizy transakcyjnej, s. 128.

${ }^{41}$ Zob. M. Dziewiecki, Komunikacja wychowawcza, s. 254-256. 
Drugie zastrzeżenie dotyczy konieczności wyakcentowania faktu, że docenianie miłosierdzia nie jest jednoznaczne z deprecjacją sprawiedliwości. Kościół konsekwentnie naucza, że „miłosierdzie nie sprzeciwia się sprawiedliwości, lecz wyraża zachowanie Boga w stosunku do grzesznika, ofiarując mu jeszcze jedną możliwość skruchy, nawrócenia i wiary. [...] Gdyby Bóg ograniczył się do sprawiedliwości, przestałby być Bogiem i byłby jak wszyscy ludzie, którzy domagają się poszanowania prawa. Sama sprawiedliwość nie wystarcza, a doświadczenie uczy, że odwoływanie się tylko do niej niesie z sobą ryzyko jej zniszczenia. [...] To nie znaczy, że umniejsza się sprawiedliwość bądź czyni ją zbędną, wręcz przeciwnie. Ten, kto błądzi, będzie musiał ponieść karę. Tyle że to nie jest ostatnie słowo, ale początek nawrócenia, ponieważ doświadcza się czułości przebaczenia. Bóg nie odrzuca sprawiedliwości. On ją umieszcza i przekracza w jeszcze większym wydarzeniu, gdzie doświadcza się miłości, która jest fundamentem prawdziwej sprawiedliwości" ${ }^{42}$. W rozumieniu biblijnym sprawiedliwość jest utożsamiana z zachowywaniem Prawa, jednakże takie ich powiązanie doprowadzało wielokrotnie do legalizmu. Toteż papież Franciszek przypomina, że chcąc przezwyciężyć tę legalistyczną perspektywę, należy pamiętać, że w Piśmie Świętym sprawiedliwość jest rozumiana zasadniczo jako pełne zaufania zdanie się na wolę Boga ${ }^{43}$.

Papieskie życzenie, aby chrześcijanie zastanowili się podczas Jubileuszu nad uczynkami miłosierdzia względem ciała i względem ducha skłania nas do refleksji, czy w tym obszarze naszego życia praktykujemy miłosierdzie. Nie pomijając uczynków miłosierdzia co do ciała, być może szczególnie powinniśmy się skupić nad realizacją - w obszarze edukacyjnym -uczynków miłosierdzia względem ducha: wątpiącym dobrze radzić, nieumiejętnych pouczać, grzeszących upominać, strapionych pocieszać, urazy chętnie darować, przykrych cierpliwie znosić, modlić się za żywych i umarłych ${ }^{44}$.

W literaturze przedmiotu zwraca się często uwagę na to, że proces porozumiewania się nauczyciela z uczniami utrudniany jest rozmaitymi zasadami, wśród których nie ma miejsca na miłosierdzie. Niezwykle uprzywilejowana pozycja nauczyciela zakłada, że to właśnie nauczyciel jako jedyny

${ }^{42}$ Zob. Mv, nr 21.

${ }^{43}$ Zob. MV, nr 20.

44 Zob. Mv, nr 15. 
ma prawo narzucania przebiegu interakcji, do niego należy zadawanie pytań i formułowanie poleceń, na nim także spoczywa prawo do oceniania tego, co zostało powiedziane i tym samym decydowania, czy to, co powie uczeń, jest prawdziwe. Mamy więc w szkole do czynienia $\mathrm{z}$ wielce asymetrycznym układem relacji, którego fundamentem jest zróżnicowany zakres uprawnień uczestników procesu nauczania - uczenia się, co skutkuje przekonaniem, że jedyną rolą ucznia jest reagowanie na polecenia wydawane przez nauczyciela i trafne odczytywanie jego intencji i oczekiwań ${ }^{45}$. Co więcej, nie ma miejsca na błędy, niewiedzę i nieumiejętność. Praktyka ta jest zdecydowanie sprzeczna z nauką Jana Pawła II, o której już wspomniano, o potrzebie zrównania pomiędzy czyniącym miłosierdzie a doznającym go, zwłaszcza że w nurcie pedagogiki dialogu bardzo wyraźnie formułuje postulat konieczności budowania podmiotowych relacji na lekcjach. Uczniowie, postrzegani jako pełnowartościowi uczestnicy procesu kształcenia, nie są tylko biorcami tego, co mają do zaoferowania nauczyciele, ale sami mają też coś do zaoferowania. Podobnie jak nauczyciel mają także swoje oczekiwania oraz mniej lub bardziej jawnie dokonują oceny lekcji, a także pracy swoich nauczycieli. Potrafią również wskazać konkretne cechy, które u katechetów szczególnie są przez nich cenione. Wypowiedzi uczniowskie na ten temat zostały zaprezentowane $\mathrm{w}$ tabeli 1 .

Tabela 1. Najbardziej cenione przez katechizowanych cechy katechetów

\begin{tabular}{llll} 
Lp. & Cechy nauczycieli & $\begin{array}{l}\text { Ilość } \\
\mathrm{n}=332\end{array}$ & $\%$ \\
\hline 1. & $\begin{array}{l}\text { Wyrozumiałość, życzliwość, dobroć, wrażliwość, dobre nasta- } \\
\text { wienie do uczniów }\end{array}$ & 64 & 19,3 \\
\hline 2. & Szczerość, prawdomówność, lojalność, uczciwość & 60 & 18,1 \\
\hline 3. & Humor & 60 & 18,1 \\
\hline
\end{tabular}

${ }^{45}$ Zob. R. Wawrzyniak-Beszterda, Doświadczenia komunikacyjne uczniów w czasie lekcji: studium empiryczne, Kraków 2002, s. 20; także M. Śnieżyński, Sztuka dialogu, Kraków 2005, s. 28. 
Lp. Cechy nauczycieli

Ilość

$\mathrm{n}=332$

$\%$

4. temu, co robi, zaangażowanie, pomysłowość, inteligencja, kompetencja

5. Szacunek dla opinii uczniów, otwartość, tolerancja, uprzejmość, chęć poznania tego, co interesuje uczniów

46

13,9

6. Cierpliwość, opanowanie, spokój, opanowanie

43

12,9

Gotowość do rozmowy, gotowość do wysłuchania każdego,

7. udzielanie odpowiedzi, poruszanie różnych tematów, bezpo-

średniość, kontaktowość

Źródło: J. Siewiora, Między monologiem a dialogiem edukacyjnym. Studium porównawcze katechezy w Polsce i na Ukrainie, Tarnów 2013, s. 263.

Z łatwością da się zaobserwować, że cechy, jakie uczniowie cenią najbardziej u swoich nauczycieli, stanowią niezwykły zbiór, który jest w dużej mierze pochodną postawy miłosierdzia. Skoro więc miłosierdzie jest cnotą, to warto pamiętać, że poprzez powtarzalność działania można je w sobie wypracować. Kontekstualnie wspierają nabywanie cnoty następujące warunki:

- trwała przynależność do pewnej wspólnoty, która zapewnia ochronę, bezpieczeństwo i społeczne uznanie;

- moralna jednomyślność lub podobieństwo normatywnych przekonań członków wspólnoty;

- relatywna trwałość ładu społecznego;

- dobre przykłady ze strony najbliższych osób;

- sensowne możliwości działania, tzw. godziwe zajęcia ${ }^{46}$.

Potrzeba uwzględniania uczniowskich oczekiwań, na równi z praktykowaniem postawy miłosierdzia w posłudze katechety czy wychowawcy, prowadzi do podjęcia próby wytyczenia konkretnych działań. Są nimi:

- miłość do uczniów, rozumiana jako zdolność do budowania duchowego ciepła, radości. „Praca miłości to jest świadome pragnienie tego, by w dzieciach utwierdzić samego siebie, przedłużyć nich swoje duchowe

${ }^{46}$ Zob. W. Brezinka, Wychowanie i pedagogika, Kraków 2008, s. 88. 
bogactwo. [...] Przedłużyć siebie w swoich dzieciach - to znaczy być mężnym w miłości" ${ }^{4}$;

- wiedza - jest wezwaniem do poznania przez wychowawców warunków fizycznego i psychicznego rozwoju dziecka, jego sukcesów i trudności w nauce, wiedzy o jego zainteresowaniach i upodobaniach, o grupie znajomych i przyjaciół;

- pomoc - ma przejawiać się nie w wykonaniu za dzieci ich obowiązków w obszarze pracy czy nauki, ale w metodycznej poradzie, jak wykonać te czy inne zadania, oraz w stworzeniu sprzyjających sytuacji dla pokonania pojawiających się trudności. Okazuje się, że w samodzielnej, wytrwałej działalności dokonuje się aktywny rozwój osobowości, natomiast wykonywanie za dziecko jego obowiązków osłabia je, zubaża jego osobowość;

- wymagania - niezbędna jest wystarczająca i obiektywna kontrola rzetelnego wykonania przez dzieci ich obowiązków zaleconych we wszystkich sferach działalności. Jeżeli systematycznie dokonuje się tej kontroli, to tym samym u dziecka stopniowo kształtuje się poczucie odpowiedzialności w wykonywaniu obowiązków i poleceń;

- prawda - bazuje na ogólnoludzkiej normie moralnej „nie kłam”, skodyfikowanej w Dekalogu jako „nie mów fałszywego świadectwa przeciw bliźniemu swemu" (Wj 20, 16). Jedynie prawda we wzajemnych relacjach dorosłych z dziećmi najlepiej wpływa na dziecko;

- wartości - zasadzają się na humanistycznej istocie wychowania. Dziecko znajduje się na początku drogi aktywnego rozwoju, wkracza w relacje $\mathrm{z}$ innymi ludźmi, popełnia błędy, ma niewiele doświadczenia i wiedzy. Mimo to, jako człowiekowi, dziecku należy się szacunek ${ }^{48}$.

\section{Zakończenie}

Celem miłosierdzia jest usunięcie zła, któremu podlega bliźni ${ }^{49}$, wskazanie to przypomina, że życie w społeczeństwie stwarza nieskończenie wiele sytuacji do praktykowania tej cnoty. Pierwszym ze sposobów usuwania zła, niekiedy zapomnianym, jest modlitwa, przez którą możemy zabiegać o pomoc Bożą dla bliźniego. Właściwe rozumienie naszej, jako duszpasterza, katechety czy wychowawcy, odpowiedzialności za drugiego człowieka,

47 V. O. Sukhomlyns'ky, My prodovzhuyemo sebe v dityakh, Kyiv 1972, s. 18.

${ }^{48}$ Zob. A. I. Kuz'mins'kyy, V. L. Omelyanenko, Pedahohika, Kyiv 2008, s. 375-376.

49 Zob. J. Woroniecki, Katolicka etyka wychowawcza, s. 28. 
każe zdobyć się na odwagę pouczania o tym wszystkim, co potrzebne jest wychowankowi do dobrego życia, a więc o prawdach wiary i udzielania rad mających pomóc we właściwym postępowaniu. Umiejętność niesienia pociechy wychowankom i podtrzymywanie ich na duchu są szczególnie ważne wówczas, gdy ich wola ulega zachwianiu i zniechęceniu. Niezwykle istotnym sprawdzianem miłości miłosiernej są sytuacje konfrontacji z brakami i ułomnościami moralnymi, wadami i przewinieniami naszych wychowanków. To właśnie miłosierdzie chrześcijańskie wymaga, aby je darować. Łączą się z nim akty miłosierdzia przejawiające się w upominaniu błądzących i trosce o uleczenie ich $\mathrm{z}$ wad.

Miłosierdzie jako kategoria życia społecznego, a w szczególności jego wymiaru pedagogicznego, jawi się zatem jako przejaw wielkości, siły i hojności oraz szczególny wyraz troski o drugiego człowieka.

\section{Bibliografia}

Albieri E., Katecheza dzisiaj, Warszawa 2003.

Brezinka W., Wychowanie i pedagogika, Kraków 2008.

Czekalski R., Katecheza komunikacją wiary, Płock 2006.

Dziewiecki M., Komunikacja wychowawcza, Kraków 2005.

Fitsula M. M., Pedahohika, Kyiv 2007.

Franciszek, Bulla ustanawiająca nadzwyczajny Jubileusz Miłosierdzia Misericordiae Vultus, Wrocław 2015.

Jan Paweł II, Encyklika Dives in misericordia, Kraków 2010.

Jarząbek L., Kompetencje pedagogiczno-osobowościowe katechetów w ich ocenie oraz w opinii uczniów, w: Struktury pedagogiczne w katechezie, red. M. Śnieżyński, Kraków 2001, s. 63-77.

Kasperkiewicz K. M., Pojęcie miłosierdzia $w$ encyklice "Dives in misericoridia”, w: Encyklika Ojca Świętego Jana Pawła II o Bożym miłosierdziu „Dives in misericordia". Tekst i komentarz, red. S. Grzybek, M. Jaworski, Kraków 1981, s. 65-75. Majka J., Miłosierdzie jako zasada społeczna w świetle encykliki „Dives in misericordia”, w: Encyklika Ojca Świętego Jana Pawła II o Bożym miłosierdziu „Dives in misericordia”. Tekst i komentarz, red. S. Grzybek, M. Jaworski, Kraków 1981, s. 175-186.

Kongregacja ds. Duchowieństwa, Dyrektorium ogólne o katechizacji, Poznań 2002. Kuz'mins'kyy A. I., Omelyanenko V. L., Pedahohika, Kyiv 2008.

Nowak M., Teorie i koncepcje wychowania, Warszawa 2008. 
O’Collins G., Farrugia E. G., Leksykon pojęć teologicznych i kościelnych, Kraków 2002. Pankowska D., Nauczyciel w perspektywie analizy transakcyjnej, Lublin 2010.

Rahner K., Vorgrimler H., Mały słownik teologiczny, Warszawa 1987.

Sukhomlyns'ky V. O., My prodovzhuyemo sebe v dityakh, Kyiv 1972.

Sztompka P., Socjologia. Analiza społeczeństwa, Kraków 2012.

Śnieżyński M., Sztuka dialogu, Kraków 2005.

Wawrzyniak-Beszterda R., Doświadczenia komunikacyjne uczniów w czasie lekcji:

studium empiryczne, Kraków 2002.

Woroniecki J., Katolicka etyka wychowawcza, Lublin 2013.

\section{Streszczenie}

Refleksja nad rzeczywistością miłosierdzia w życiu społecznym, a więc także w przestrzeni pedagogicznej, prowadzi do poszukiwania odpowiedzi na pytanie, czy miłosierdzie jest oznaką słabości i rezygnacji z wymagań, czy przeciwnie - jest raczej znakiem rzetelnej troski o jakość życia społecznego i rozwój młodego pokolenia. Artykuł jest próbą poszukiwań odpowiedzi na to kluczowe pytanie i wypływające z niego problemy szczegółowe, w oparciu o wiedzę teologiczną i pedagogiczną.

\section{Słowa kluczowe}

miłosierdzie, przestrzeń pedagogiczna, odwaga głoszenia prawdy, przebaczenie

\section{Summary}

\section{Mercy as a Category of Social Life}

Reflection on the reality of mercy in social life, and also in the pedagogical space, leads to the question of whether the mercy is a sign of weakness and lowering of expectations, or rather a sign of fair care about the quality of life and development of the young generation. Presented article is an attempt, based on theological and pedagogical knowledge, to find answers to this key question, and to specific problems arising from it.

\section{Keywords}

mercy, pedagogical space, the courage to proclaim the truth, forgiveness 